Article

\title{
Contribution of Tropical Cyclones to Precipitation around Reclaimed Islands in the South China Sea
}

\author{
Dongxu Yao ${ }^{1,2}$, Xianfang Song ${ }^{1,2, *}$, Lihu Yang ${ }^{1,2, *}$ and Ying Ma ${ }^{1}$ \\ 1 Key Laboratory of Water Cycle and Related Land Surface Processes, Institute of Geographic Sciences and \\ Natural Resources Research, Chinese Academy of Sciences, Beijing 100101, China; \\ yaodongxu16@mails.ucas.edu.cn (D.Y.); maying@igsnrr.ac.cn (Y.M.) \\ 2 Sino-Danish College, University of Chinese Academy of Sciences, Beijing 100049, China \\ * Correspondence: songxf@igsnrr.ac.cn (X.S.); yanglihu@igsnrr.ac.cn (L.Y.); Tel.: +86-010-6488-9849 (X.S.); \\ +86-010-6488-8266 (L.Y.)
}

Received: 15 September 2020; Accepted: 2 November 2020; Published: 5 November 2020

\begin{abstract}
Tropical cyclones (TCs) play an important role in the precipitation of tropical oceans and islands. The temporal and spatial characteristics of precipitation have become more complex in recent years with climate change. Global warming tips the original water and energy balance in oceans and atmosphere, giving rise to extreme precipitation events. In this study, the monthly precipitation ratio method, spatial analysis, and correlation analysis were employed to detect variations in precipitation in the South China Sea (SCS). The results showed that the contribution of TCs was $5.9 \%$ to $10.1 \%$ in the rainy season and $7.9 \%$ to $16.8 \%$ in the dry season. The seven islands have the same annual variations in the precipitation contributed by TCs. An $800 \mathrm{~km}$ radius of interest was better for representing the contribution of TC-derived precipitation than a $500 \mathrm{~km}$ conventional radius around reclaimed islands in the SCS. Four track patterns of TCs were defined. The order according to the primary pattern of contribution was I $(26-85.3 \%)>$ IV $(12.8-29.8 \%)>$ III $(4.3-29 \%)>$ II (11.5-24\%). The average distance between islands and TCs was 1163 and $712 \mathrm{~km}$ in the rainy and dry seasons, respectively. The average contribution was larger in La Niña than in El Niño periods. These results could be beneficial for managing rainwater resources, especially the TC-induced precipitation in the reclaimed islands.
\end{abstract}

Keywords: tropical cyclones; precipitation; reclaimed islands; ENSO; South China Sea

\section{Introduction}

Precipitation is a major natural source of fresh water for maintaining ecological balance and promoting the sustainable development of islands and reefs in the tropical Pacific. Total precipitation can be separated into tropical cyclone (TC) precipitation and non-TC precipitation (e.g., seasonal rainfall) [1,2]. TCs are important contributors to precipitation in the tropical marine areas and islands [3-5]. Such contribution varies significantly across different land and sea areas of the world. For instance, in Mexico, the highest contribution of TCs was $40 \%$ of total annual rainfall from 2001 to 2013 [6]. In the Mekong River Basin, the largest contribution of TC precipitation for 34 years was 12.4\% [7]. On the Australian coast, the maximum percentage contribution of TC-induced precipitation was $55 \%$ [8]. At the global scale, TCs contributed to about $35-50 \%$ of annual precipitation [9]. Precipitation controls the formation and evolution of freshwater lenses through regulating recharge in reclaimed islands [10-14]. Therefore, the proportions of TC-induced precipitation are important.

TCs are the dominant drivers for the occurrence of precipitation in the South China Sea (SCS), as the SCS is one of the origins of TCs and is frequently affected each year [15,16]. Available information indicates that the increased contribution of TC-induced precipitation to summer rainfall was $30 \%$ along the coastal regions in southern China [17]. The larger interannual variations of September and October 
rainfall in Hainan for the period of 1965-2010 were in the wet years [18]. The frequency of TCs over the SCS is increasing, due to ever more TCs moving into the SCS from elsewhere [19], then leading to autumn precipitation in Central Vietnam [20]. Furthermore, because the rate of infiltration into the coral sands is higher than the precipitation rate, the surface water flow and freshwater lakes on the small coral reefs and reclaimed islands in the SCS are insufficient. In the dry season, a lack of rainfall recharge has adverse effects on freshwater lenses, even leading to extinction [21,22]. Consequently, TC-induced precipitation is affected by the frequency of TCs, with seasonal variations, thereby controlling the volumes of freshwater lenses.

El Niño-Southern Oscillation (ENSO) and sea surface temperature (SST) have obvious impacts on TCs and precipitation [19]. El Niño events have been confirmed to trigger abnormal western North Pacific (WNP) cyclones in August 2016. The SST of the western Indian Ocean and tropical North Atlantic (TNA) also plays an important role in influencing southern China precipitation [23]. The warm SST anomalies in the northern SCS and the WNP over the past 50 years enhanced mean moisture transport into Taiwan, Hainan, and adjacent islands, which led to more seasonal rainfall over southern China $[2,20,24]$. In the cold TNA SST years during the period of 1977-2016, more TCs were generated over the SCS, as their genesis frequency and location were regulated by the TNA SST [25]. However, results from a regional climate modeling system show that the ENSO has less influence on TC activity in terms of interannual variation, although landfalling TCs in the WNP tend to be more intense [26]. In addition, some studies focus on the effects of different tracks. For example, the forming location and track patterns of TCs have a major impact on TC-induced precipitation [27]. However, they tend to ignore the attributes of the motion between islands and the TC's center. Thus, although there have been many investigations on the ENSO and SST anomaly in the SCS region, few studies have considered the contribution of TCs to precipitation and the track pattern of TCs in the reclaimed islands.

The scope of TC-induced precipitation was defined as a circle with an effective radius at the global or regional scale, which was made use of in investigating rainfall in the inner-core region $(0-100 \mathrm{~km})$ and outer region (100-300 km) in light of Tropical Rainfall Measuring Mission (TRMM) data [28]. Extreme precipitation was found more than $450 \mathrm{~km}$ away from the storm center [29], in accordance with many other studies [30-33], within the effective radius of $500 \mathrm{~km}$. Although definitions of TCs based on a circle with an effective radius have been widely employed, the effective radii are different in other studies, ranging from 400 to $1000 \mathrm{~km}[34,35]$. Hence, we set out to confirm the optimum effective radius around the region of reclaimed islands in the SCS. Spatial statistics and correlation-analysis methods were applied to examine the best-track data and correlation between TC-induced precipitation and ENSO.

The study firstly describes the spatiotemporal variation of TCs and characteristics of precipitation together with ENSO, and then explores the monthly, seasonal, and interannual contribution of TCs to precipitation in the reclaimed islands. The major objectives of this study were therefore to (1) quantify annual and interannual features of TCs (intensity and tracks) and TC-induced precipitation rates, (2) determine the radius of TC-derived precipitation in reclaimed islands of the SCS, and (3) analyze the impacts of the track pattern of TCs and ENSO in terms of the contribution of TC-induced precipitation. This should help to clarify the contribution of TCs to precipitation and interfering factors in the reclaimed islands of the SCS. The findings of this study will be beneficial for deciding upon reasonable measures to supply freshwater to maintain the stability of freshwater lenses, especially in the dry season.

\section{Materials and Methods}

\subsection{Study Area}

The study area is located in the SCS, at approximately $4-25^{\circ} \mathrm{N}$ and $100-125^{\circ} \mathrm{E}$, and the major area of research covers seven reclaimed coral islands: Mischief Reef (MJ), Subi Reef (ZB), Fiery Cross Reef (YS), Caurteron Reef (HY), Gaven Reef (NX), Hughes Reef (DM), and Johnson South Reef (CG). 
The focus of the study is on the reclaimed coral islands, where freshwater lenses may exist (Figure 1) and will herein be referred to as the potential places for human survival and ecological water demand. The Spratly Islands belong to the tropical marine monsoon climate zone, which is characterized by a dry season (January-May) and rainy season (June-December).

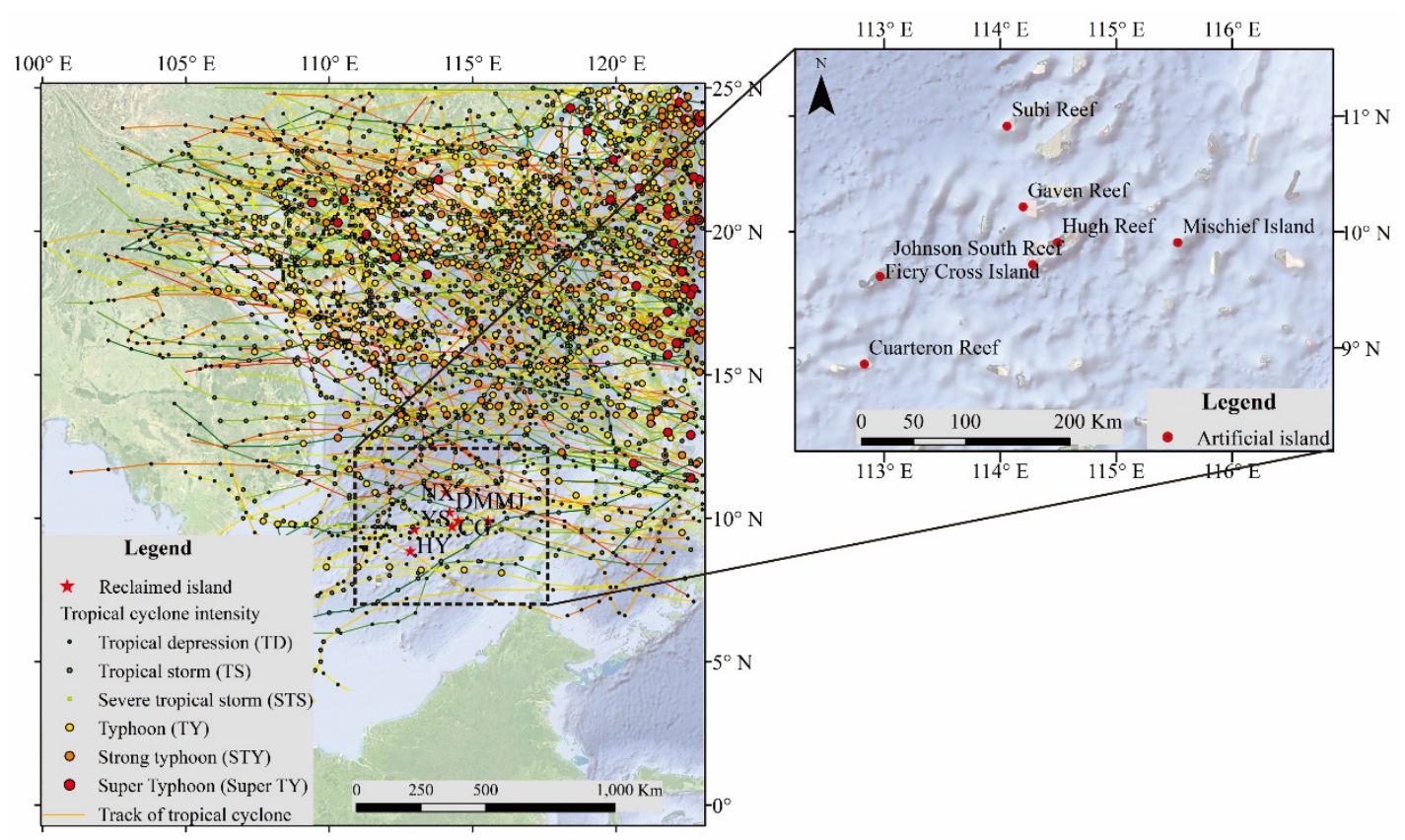

Figure 1. Map showing reclaimed islands in the SCS with the tracks and grades of the TCs.

\subsection{Data}

The data of half-hourly precipitation (GPM IMERG Final Precipitation L3 Half Hourly $0.1^{\circ} \times 0.1^{\circ}$ V06) in the SCS during 2001-2018 were collected from Global Precipitation Measurement (https://gpm.nasa.gov/data/directory) [36]. We selected seven points to represent seven different reclaimed islands (Figure 1) and obtained daily and monthly precipitation data by summing the half-hourly meteorological data.

The best-track data for each TC at $6 \mathrm{~h}$ time intervals from 2001 to 2018 were obtained from the Shanghai Typhoon Institute (STI) of the China Meteorological Administration (http://TCdata.typhoon. org.cn/), including the latitude-longitude position, the maximum sustained surface wind speed (WND), and the minimum central pressure. The quality of the TC tracks was controlled using the method of Ying et al. [37]. Due to uncertainties in tracking tropical depressions, we excluded the contribution of tropical depressions to precipitation in this study, but we showed the spatial variation of tropical depressions (Figure 1).

ENSO phases were derived from SST anomalies in the region $5^{\circ} \mathrm{N}-5^{\circ} \mathrm{S}, 170^{\circ}-120^{\circ} \mathrm{W}$ (i.e., Niño-3.4), which is also the most important region for WNP TC activities [38]. Monthly ENSO data were obtained from the Climate Prediction Center of the National Oceanic and Atmospheric Administration (https://www.cpc.ncep.noaa.gov).

In situ data were measured by using rain barrels on two islands (MJ island and YS island), including daily and monthly precipitation data. The daily data were for 24 May to 11 June 2017 on MJ island, and the monthly data were for August 2015 to July 2016 on YS island. 


\subsection{Methods}

\subsubsection{The Monthly Precipitation Ratio (MPR)}

The TC-induced precipitation $\left(P_{T C s}\right)$ ratio $(T P R)$ was defined as the ratio of summed TC-induced daily precipitation $\left(P_{D}\right)$ to monthly total precipitation $\left(P_{\text {Total }}\right)$ [7]. The $P_{T C S}$ was defined by the distance between the six-hourly interpolated tropical cyclone center and the island.

$$
\begin{gathered}
\text { TPR }=\frac{\sum_{i=1}^{m} P_{T C S}}{P_{\text {Total }}} \times 100 \% \\
P_{\text {Total }}=\sum_{j=1}^{n} P_{D}
\end{gathered}
$$

where TPR is the $P_{T C S}$ ratio, $\mathrm{m}$ is the number of days of TCs, $P_{T C S}$ is TC-induced precipitation, $P_{\text {Total }}$ is monthly total precipitation, and $\mathrm{n}$ is the days of a month.

\subsubsection{Spatial Analysis and Statistics}

We used the Arc Toolbox including Data Management Tools and Analysis Tools to analyze the best-track data for each TC obtained at $6 \mathrm{~h}$ time intervals from 2001 to 2018. The TCs were also classified and summarized. All the spatial analytical processes were completed in ArcGIS 10.5 (ESRI, Redlands, CA, USA).

\subsubsection{Correlation Analysis}

Pearson correlation coefficient was used to assess correlation between precipitation and ENSO at the $p<0.01$ and $p<0.05$ levels (two-tailed) over the years. If the $\mathrm{p}$ value is less than 0.05 , the result is considered statistically significant and can be accepted. All the statistical analyses were performed using SPSS 22.0 (Statistical Package for the Social Sciences (IBM, Armonk, NY, USA)).

\subsubsection{El Niño and La Niña Events}

In order to investigate the relationship between TC-induced precipitation and El Niño-Southern Oscillation (ENSO) phases, a classification of El Niño and La Niña events for the years 2001-2018 was used. The classification was based on the National Criterion GB/T 33666-2017 using three-month averages of the Niño-3.4 index [39]. When the index was $\geq 0.5^{\circ} \mathrm{C}\left(\leq-0.5^{\circ} \mathrm{C}\right)$ for at least five months, an El Niño (La Niña) event was identified. According to this criterion, seven El Niño periods and eight La Niña periods were identified.

\section{Results}

\subsection{Spatiotemporal Variation of TCS}

Table 1 shows the proportions of TCs of six different grades: Tropical depression (TD), Tropical storm (TS), Severe tropical storm (STS), Typhoon (TY), Strong typhoon (STY), and super typhoon [27]. Obviously, TYs, STYs, and super typhoons accounted for only $13.5 \%$. TSs and STSs accounted for $42.8 \%$, and TDs, $36.9 \%$. Therefore, approximately $80 \%$ of the TCs were equally or less intense than STSs.

The best-track data for the maximum sustained surface wind speed (WND) of each TC collected at $6 \mathrm{~h}$ time intervals from 2001 to 2018 were analyzed. The spatial distribution of the TCs, along with intensity (Table 1) and tracks, are shown in Figure 1. TCs with six different intensities had complicated spatial distributions. Super typhoons were located in the northeast (lying north of $10^{\circ} \mathrm{N}$ and east of $108^{\circ} \mathrm{E}$ ) of the reclaimed islands. The distribution range for TYs was more than $8^{\circ} \mathrm{N}$ and $106^{\circ} \mathrm{E}$. The TCs around the reclaimed islands mainly consisted of TDs, TSs, and STSs. The TCs track almost covered the whole sea area above $5^{\circ} \mathrm{N}$, and no TCs occurred in the tropics with a latitude lower than 
$4^{\circ} \mathrm{N}$. The TCs mainly moved from the eastern Pacific Ocean to the western Eurasian continent and even land.

Table 1. Grades of TCs and proportion over 18 years (2001-2018).

\begin{tabular}{cccc}
\hline Grade of TCs & Proportion (\%) & Maximum Average Wind Speed (m/s) & Intensity \\
\hline Tropical depression (TD) & 36.9 & $10.8-17.1$ & 1 \\
Tropical storm (TS) & 29.0 & $17.2-24.4$ & 2 \\
Severe tropical storm (STS) & 13.8 & $24.5-32.6$ & 3 \\
Typhoon (TY) & 13.5 & $32.7-41.4$ & 4 \\
Strong typhoon (STY) & 5.6 & $41.5-50.9$ & 5 \\
Super typhoon (Super TY) & 1.2 & $\geq 51.0$ & 6 \\
\hline
\end{tabular}

Figure 2 shows the spatial distribution of TCs from 2001 to 2018. The whole area is divided into small squares $\left(1^{\circ} \times 1^{\circ}\right)$ to analyze the numbers of TC centers in space. The squares with more than 20 TC centers each were located to the northeast of the reclaimed islands, except for two squares with 10 and 15 TCs, separately. Squares with more than 10 centers each were located north of $10^{\circ} \mathrm{N}$, and a square with even 32 was located north of $16^{\circ} \mathrm{N}$.

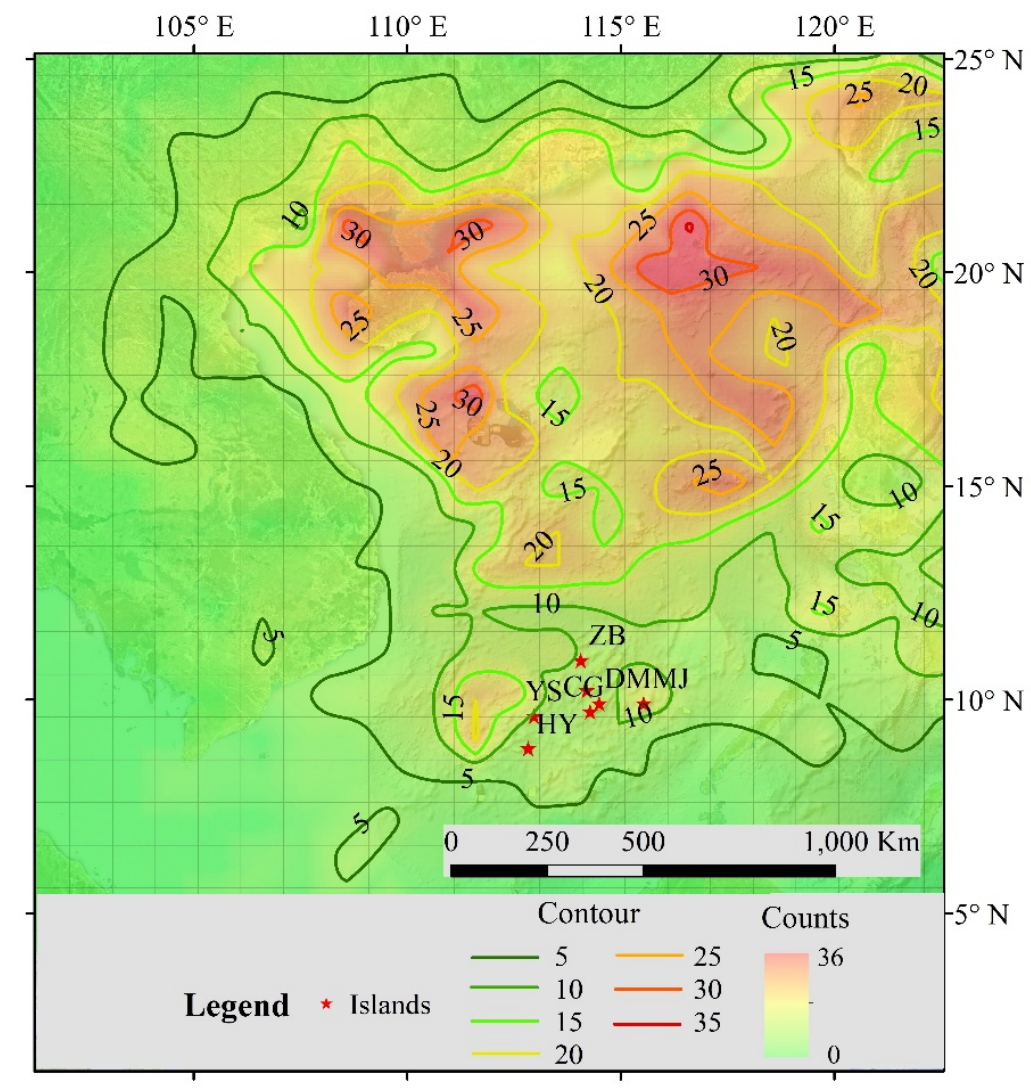

Figure 2. Spatial distribution of TCs over 18 years (2001-2018).

The TCs were generally concentrated between July and October, hardly occurring between January and April. At least one tropical cyclone occurred between July and September each year. There were four TCs in February, the least TC-prone month over the 18 years (2001-2018). September was the most prone month, in which a total of 46 TCs occurred from 2001 to 2018 . There were rarely more than five cyclones in a single month (Figure 3a). 

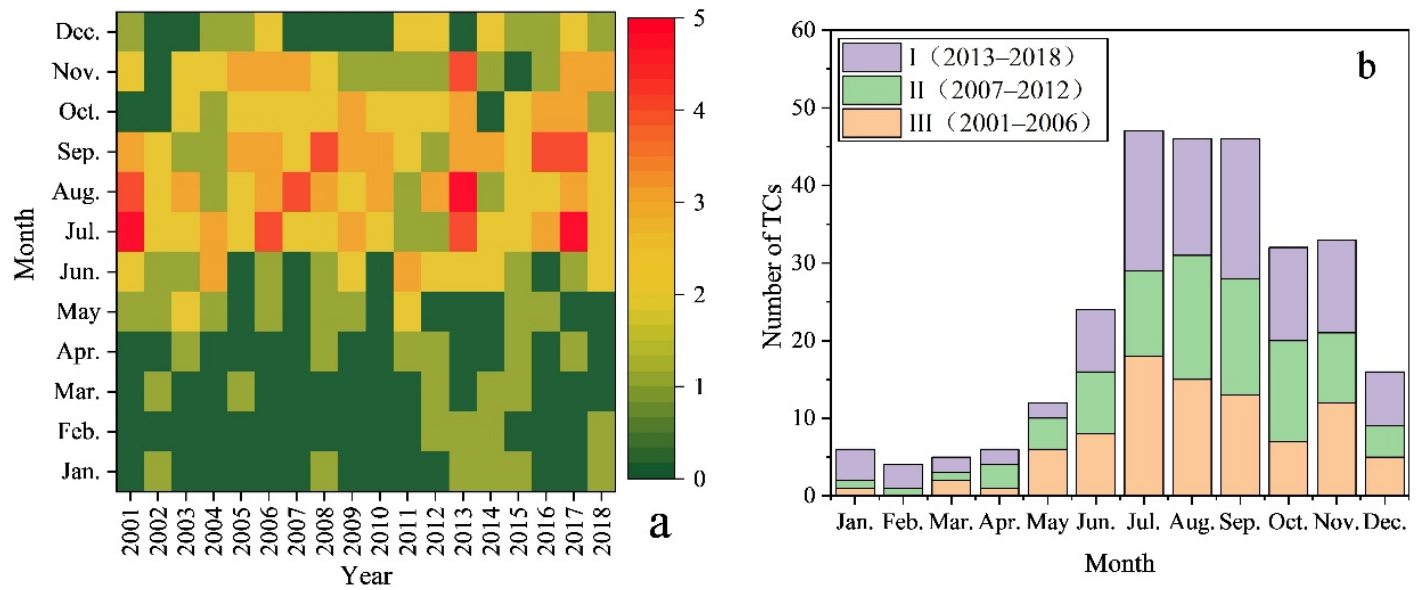

Figure 3. (a) Distributions of TCs in different years (2001-2018); (b) average monthly occurrence of TCs in different stages.

The transformation in average monthly numbers of TCs was found in three different stages that every seven years was divided from 2001 to 2018 (Figure 3b). The numbers of TCs in the three most TC-prone months (July, August, and September) were five times those in the four least TC-prone months (January, February, March, and April). The frequency of TCs in the first stage was $17 \%$ higher than that in the third, while that in the second was the same as that in the third. In the rainy season, the frequency of TCs was $15.4 \%$ higher in the first stage than that in the third. In the dry season, the number of TCs was 30\% higher in the first stage than that in the third. Obviously, the frequency of TCs increased owing to climate change in recent years.

\subsection{Characteristics of Precipitation and ENSO}

The proportions of the different grades of precipitation on seven islands were analyzed. The statistical data for the 21 years showed that days of light rain accounted for $51.9-53 \%$ of the year; moderately rainy days, $8.2-9.2 \%$; and heavily (or above) rainy days, less than $10 \%$. The results indicated that light and moderate rain were similarly dominant in the seven reclaimed islands. Meanwhile, days without rain accounted for $28.7-30.6 \%$ of the whole year (Figure $4 a$ ). Figure $4 \mathrm{~b}$ shows that the rate of contribution to precipitation was negatively correlated with the rainfall intensity. For example, the contribution of light rain was only $11.5-11.9 \%$, that of moderate rain was $16.1-17.9 \%$, and that of heavy (or above) rain was over $65 \%$. It was therefore crucial to quantify the contribution of TCs to rainfall, as TCs usually bring extreme rainfall.

Precipitation in the rainy season was higher than the mean precipitation at most times and conversely, that in the dry season was almost lower than the mean precipitation. From the point of developing trend, more and more precipitation has occurred in the rainy seasons in recent years, aggravating the unevenness of seasonal precipitation (Figure 5a-g). The SST was intricately distributed in the grid consisting of months and years with El Niño and La Niña events alternatively occurring annually and monthly (Figure $5 \mathrm{~h}$ ). The lowest temperature $\left(-1.7^{\circ} \mathrm{C}\right)$ occurred in January 2000, and October and November 2010. The highest temperatures $\left(2.4-2.6^{\circ} \mathrm{C}\right)$ occurred in December 2015, January 2016, November 2015, and October 2015. Therefore, the most obvious anomalies occurred in the dry season. 

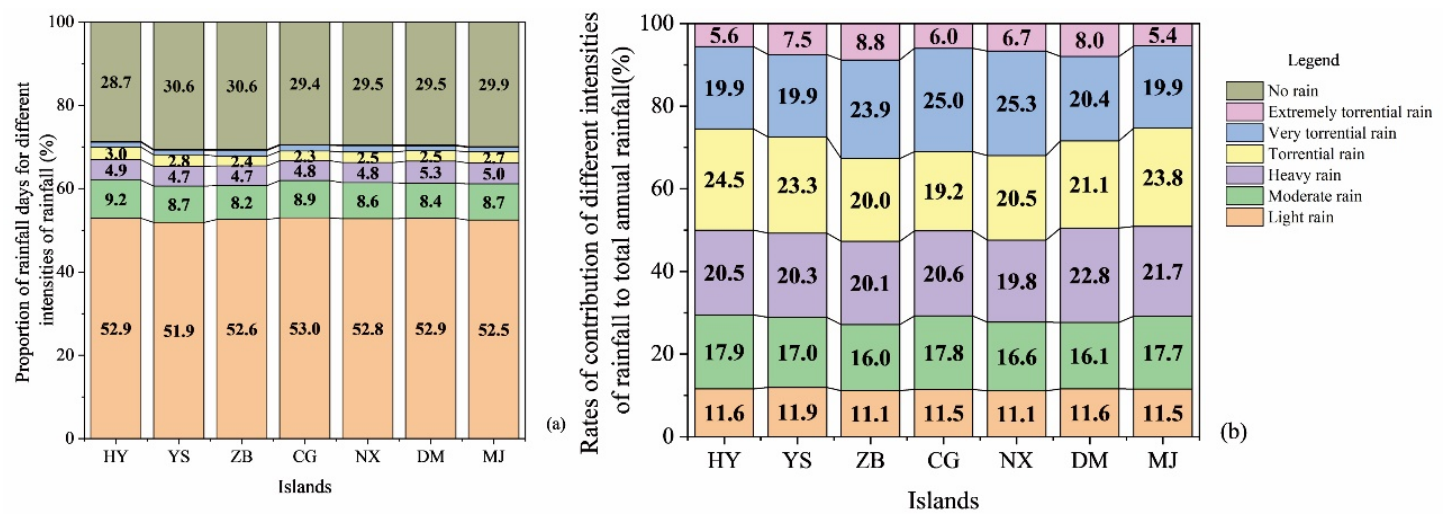

Figure 4. (a) Proportion of rainfall days by rainfall intensity; (b) rates of contribution of different intensities of rainfall to total annual rainfall.
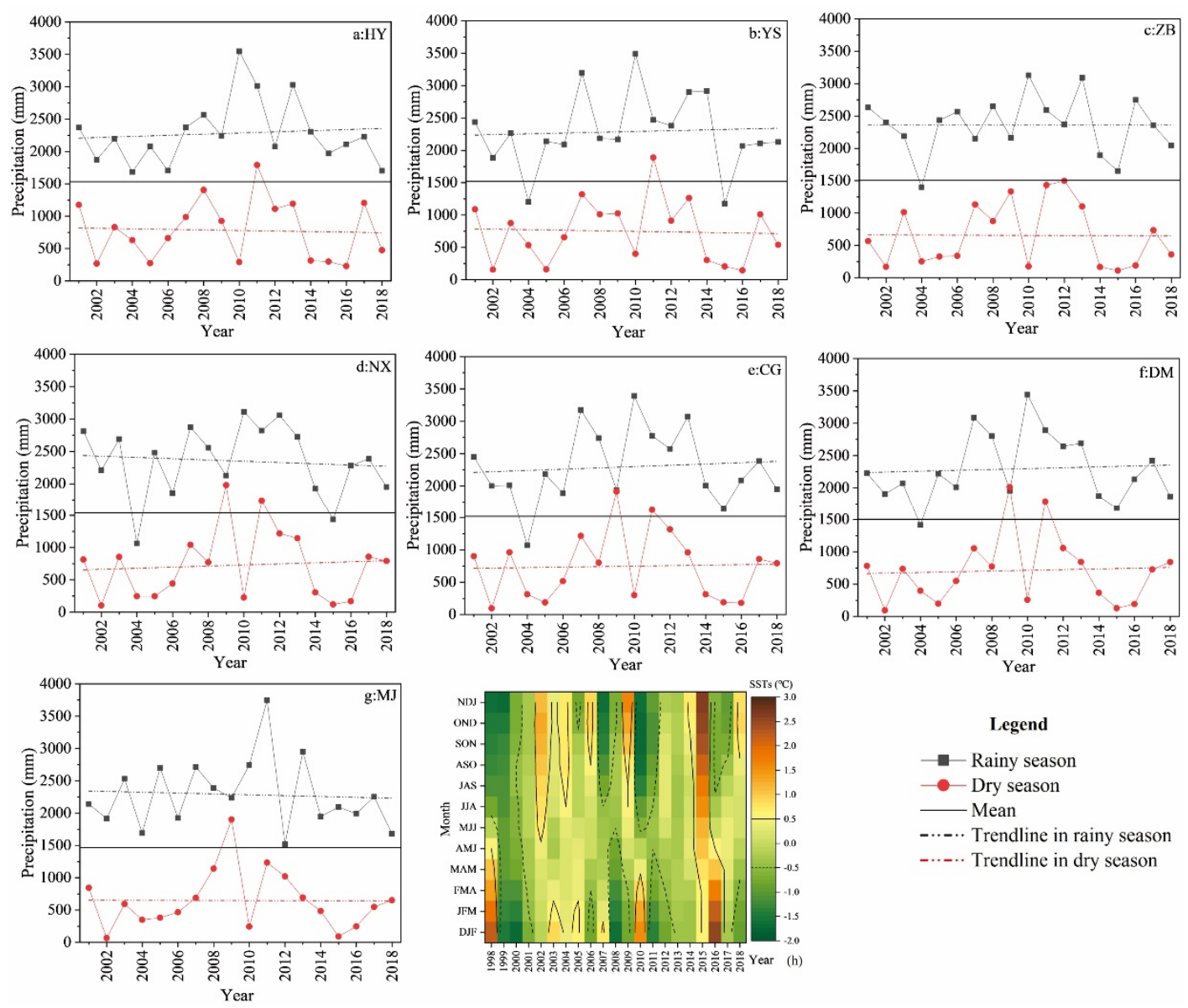

Figure 5. Precipitation in rainy and dry seasons on seven reclaimed islands (a-g); the mean was half of the annual mean precipitation. Monthly distribution of ENSO in different years (h), black solid line is $+5{ }^{\circ} \mathrm{C}$, and black dotted line is $-5^{\circ} \mathrm{C}$. 


\subsection{Monthly and Seasonal Contribution of TC-Induced Precipitation}

The monthly precipitation can be decomposed into two components: TC-induced precipitation (PTCs) and non-TC-induced precipitation $\left(\mathrm{P}_{\mathrm{N}}\right)$. Figure 6 shows the average monthly $(\mathbf{a}-\mathrm{g})$ and seasonal (h) contribution of TCs to precipitation in the radii of $500 \mathrm{~km}$ and $800 \mathrm{~km}$.
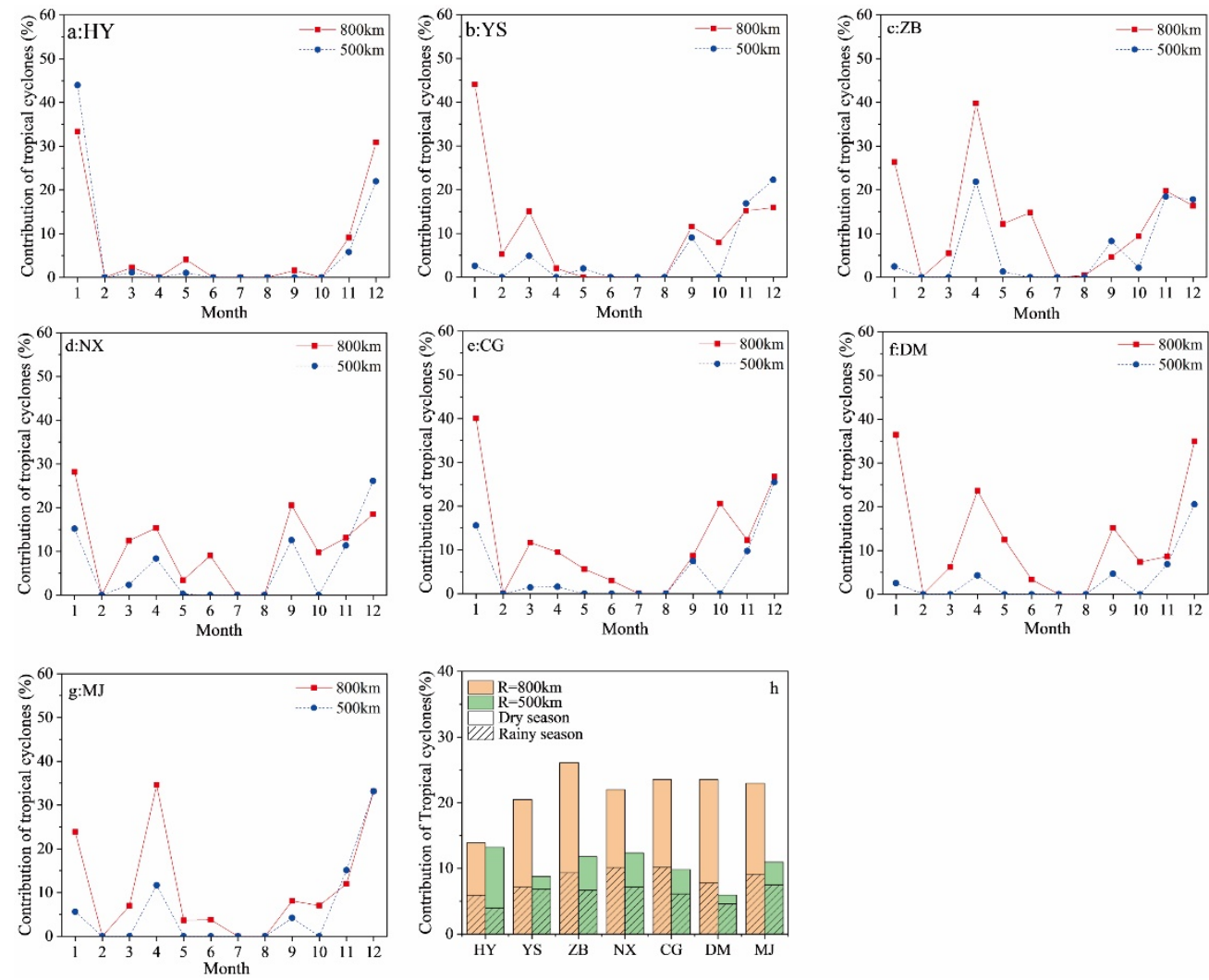

Figure 6. Average monthly (a-g) and seasonal (h) contribution of TC-induced precipitation.

When the radius was $800 \mathrm{~km}$, all seven islands had two peaks in January and December. According to the months in which the peaks occurred, the seven islands could be separated into two groups: (I) DM, NX, ZB, and MJ; (II) HY, CG, and YS. In Group I, the third peak in April (15.4-39.8\%) was the same. In Group II, they had the same third peaks in March (2.3-15\%). Furthermore, all of the islands had two minimum contribution rates in July (0\%) and August (0\%). In addition, when the radius was $500 \mathrm{~km}$, although all seven islands had the same trends as the radius of $800 \mathrm{~km}$, all had at least 2 minimum contribution rates. Obviously, TC-induced precipitation was underestimated in the radius of $500 \mathrm{~km}$, especially in the rainy season, as the smaller radius could not cover all the TC-induced precipitation areas around the reclaimed islands.

The rainy season (dry season) contribution was the average contribution over six months in the rainy season (dry season). Figure 6h displays the seasonal contribution of TCs to precipitation in the radii of $500 \mathrm{~km}$ and $800 \mathrm{~km}$. In the radius of $800 \mathrm{~km}$, contribution in the rainy season ranged from $5.9 \%$ to $10.1 \%$, while that in the dry season ranged from $7.9 \%$ to $16.8 \%$. When the radius was $500 \mathrm{~km}$, contribution in the rainy season was $4.0 \%$ to $7.5 \%$, and that in the dry season was $1.4 \%$ to $9.2 \%$. The contributions of the rainy and dry seasons were, respectively, underestimated by $1.9-2.6 \%$ and $6.5-7.6 \%$ in the radius of $500 \mathrm{~km}$ compared to those determined in the radius of $800 \mathrm{~km}$. However, the radius of $500 \mathrm{~km}$ was too small to contain all the TC-derived precipitation around the islands; consequently, the contributions were underestimated. 


\subsection{Interannual Contribution of TC-induced Precipitation}

Figure 7 displays the interannual contribution of TCs to precipitation and SST during 2001-2018. The interannual contribution of TC-derived precipitation included the seven islands with the radii of $800 \mathrm{~km}$ (Figure 7b) and $500 \mathrm{~km}$ (Figure 7c). Figure 7a shows the SST anomalies for the 18-year period. The highest SST anomaly was $1.5^{\circ} \mathrm{C}$ in 2015 , and the lowest was $-1.2{ }^{\circ} \mathrm{C}$ in 1999 . Two records (in 2002 and 2015) were higher than $+0.5^{\circ} \mathrm{C}$, and three records (in 2007, 2008, and 2011) were lower than $-0.5^{\circ} \mathrm{C}$. The seven islands have the same annual variations in the precipitation contributed by TCs. When the radius was $800 \mathrm{~km}$ (Figure $7 \mathrm{~b}$ ), the four highest contributions of TC-induced precipitation were almost zero in 2007, 2011, 2013, and 2017. When the radius was $500 \mathrm{~km}$ (Figure 8c), the highest contributions were $2-6 \%$ lower for the same years.

The trends in the precipitation contributed by TCs were similar, but the contribution rate was clearly lower, by $2-6 \%$, when the radius was $500 \mathrm{~km}$ than when it was $800 \mathrm{~km}$. Hence, the contribution rate was underestimated with the $500 \mathrm{~km}$ radius. When the SST was $>0.5^{\circ} \mathrm{C}$, the contribution rate was close to zero, and when the SST fluctuated around zero, the contribution rate was the highest. However, the two records for 2010 could not be explained, because using the mean SST meant that the distribution of SST within or across years could not be analyzed. Therefore, the relationship between TCs and ENSO according to El Niño and La Niña event is discussed in Section 4.3.

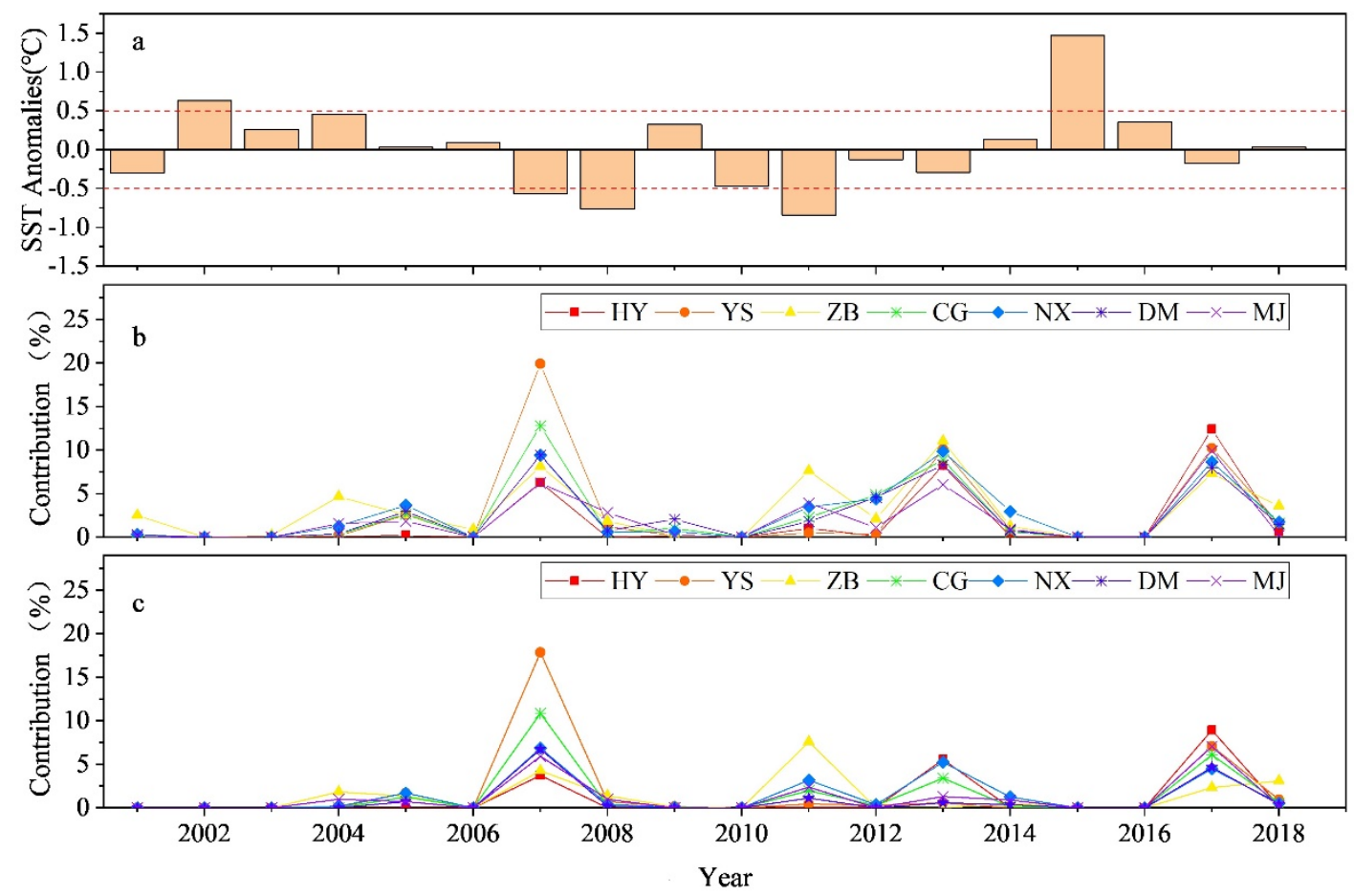

Figure 7. Annual contribution of TCs and SST during 2001-2018. (a) SST anomalies (dotted lines are $\pm 0.5^{\circ} \mathrm{C}$ ); (b) annual contribution of TCs during 2001-2018 (when the distance between the tropical cyclone center and island is $800 \mathrm{~km}$ ); (c) annual contribution of TCs during 2001-2018 (when the distance between the tropical cyclone center and island is $500 \mathrm{~km}$ ). 

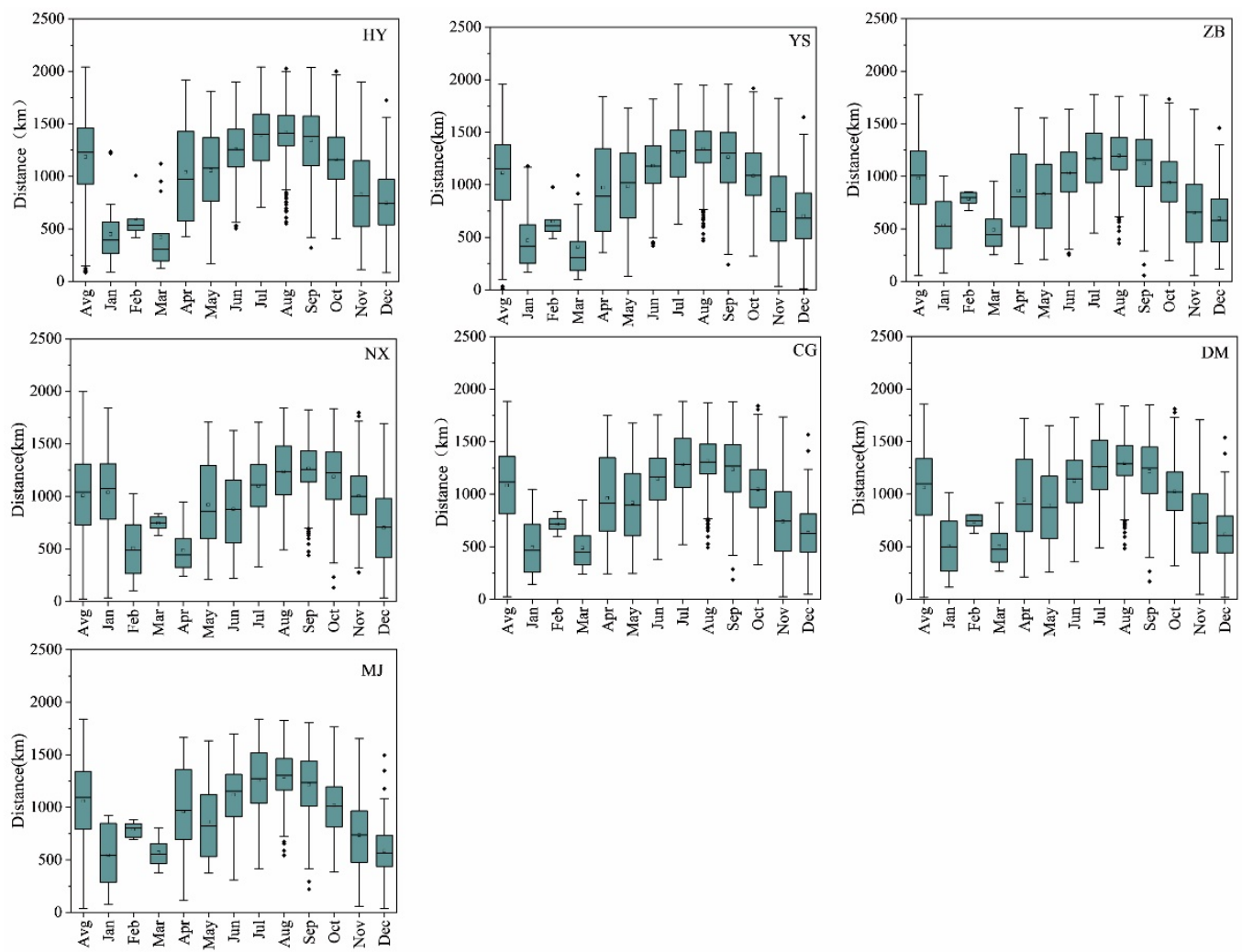

Figure 8. Monthly distribution of radii (distances between tropical cyclone center and island) in the period 2001-2018.

\section{Discussion}

\subsection{Influence of Radius on TC-Derived Precipitation}

The radius defined by the distance between the six-hourly interpolated tropical cyclone center and island varied between months and years. For instance, the TC tracks were closer to Hainan island in the dry than in the wet years in September and October in 1965-2010 [18]. Figure 8 shows the distance between the tropical cyclone center and island. Taking CG as an example, the three nearest months were January (mean, $450 \mathrm{~km}$ ), February (mean, $595 \mathrm{~km}$ ), and March (mean, $420 \mathrm{~km}$ ), while the four farthest months were June (mean, $1258 \mathrm{~km}$ ), July (mean, $1390 \mathrm{~km}$ ), August (mean, $1420 \mathrm{~km}$ ), and September (mean, $1342 \mathrm{~km}$ ). The average radii were $1163 \mathrm{~km}$ and $712 \mathrm{~km}$ in the rainy and dry seasons, respectively. The radius was larger than $500 \mathrm{~km}$ as we considered both the precipitation originated from rainband and the pre-precipitation. In a word, we think it was the contribution of TC to total precipitation as long as the rainfall was caused by TC. Moreover, the differences in radius led to two groups divided according to interannual contribution of TC-induced precipitation. There are two possible explanations for the inaccuracy when using the $500 \mathrm{~km}$ radius in our study area. Firstly, the radius of $500 \mathrm{~km}$ was defined in a static climatological view, so it varied between different regions [34]. Secondly, preliminary work mainly considered the landfall TCs but neglected the initial stage of tropical cyclone motion at sea [8]. The optimal radius for defining TC-induced precipitation will be critical for improving the forecast of the contribution of TC-induced precipitation in the future.

The numbers of TCs at different distances were variable because of the continuous movement of TCs. Although the number of events increased beyond $800 \mathrm{~km}$, it rained on the ocean instead of producing effective rainfall on the island, resulting in the contribution of TC-induced precipitation on the islands decreasing as calculated by Formulas (1) and (2). The number of TCs was less than 100 when the distance was less than $500 \mathrm{~km}$. When the distance was larger than $500 \mathrm{~km}$, the increase in TCs approximately followed a quadratic curve (Figure 9). 


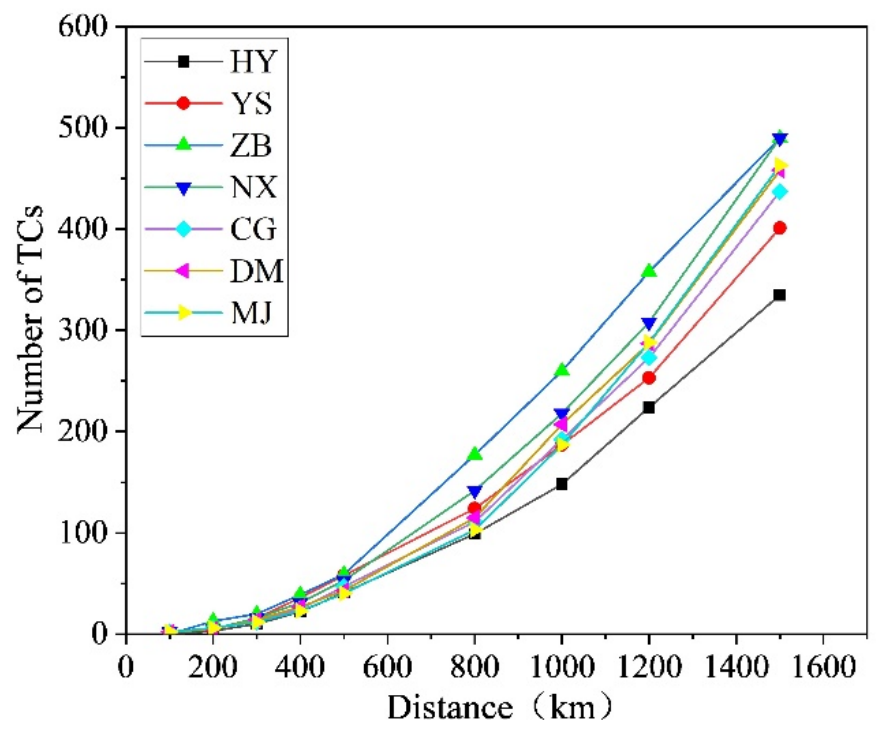

Figure 9. Numbers of TCs at different distances (between TCs' centers and islands).

\subsection{Track Patterns of TCS}

According to the relationship between the position of the tropical cyclone and its sphere of interest and the motion process of the TCs, four types of track modes were defined (Figure 10): (I) both the initial and terminal points were inside the sphere of interest; (II) the initial point was inside but the terminal point was outside the sphere of interest; (III) the initial point was outside but the terminal point was inside the sphere of interest; (IV) both the initial and terminal points were outside the sphere of interest.
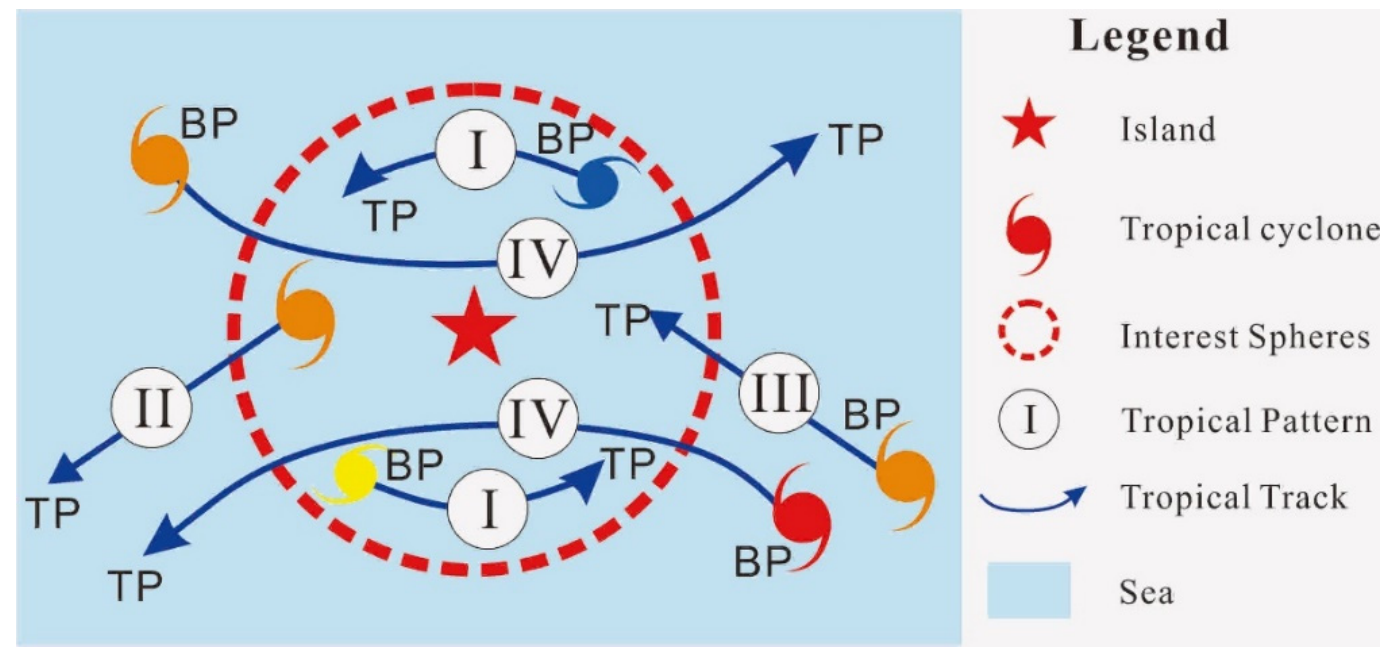

Figure 10. Map of tropical cyclone track patterns.

The influence of these four types of patterns on precipitation was different: pattern (I) remained unchanged inside as the radius increased, so it could maintain a continuous contribution to precipitation; pattern (II) moved away from the island as the radius increased; pattern (III) remained close to the island as the radius increased; and pattern (IV) was able to convert to pattern (I) as the radius increased. Therefore, the four different types of tropical cyclone track patterns could lead to significant impact between distance and precipitation as shown in Figure 11. 
Figure 11 shows the numbers of TCs in four track patterns with radii of 500 and $800 \mathrm{~km}$ over the 18 years. Track patterns II and IV represented the greatest numbers. Track pattern I existed only in HY and YS when the radius was $500 \mathrm{~km}$ (Figure 11a), while it did not exist only in MJ when the radius was $800 \mathrm{~km}$ (Figure 11b). TCs of track pattern II occurred 5-14 times in the seven islands within the radius of $800 \mathrm{~km}$, but that number was about half within the radius of $500 \mathrm{~km}$. For instance, there were 14 TCs of track pattern II (the most) in ZB and 5 (the least) in HY when the radius was $800 \mathrm{~km}$, while there were 7 and 1, respectively, when the radius was $500 \mathrm{~km}$. Track pattern III happened 5-9 times within the radius of $800 \mathrm{~km}$ and 1-2 times in that of $500 \mathrm{~km}$. Similarly, track pattern IV occurred 21-35 times within $800 \mathrm{~km}$ and 19-25 times within $500 \mathrm{~km}$. In brief, a larger radius enables the more accurate quantification of TCs of the four track patterns, owing to the average distance between the TCs and islands being approximately $1000 \mathrm{~km}$, as shown in Figure 8.
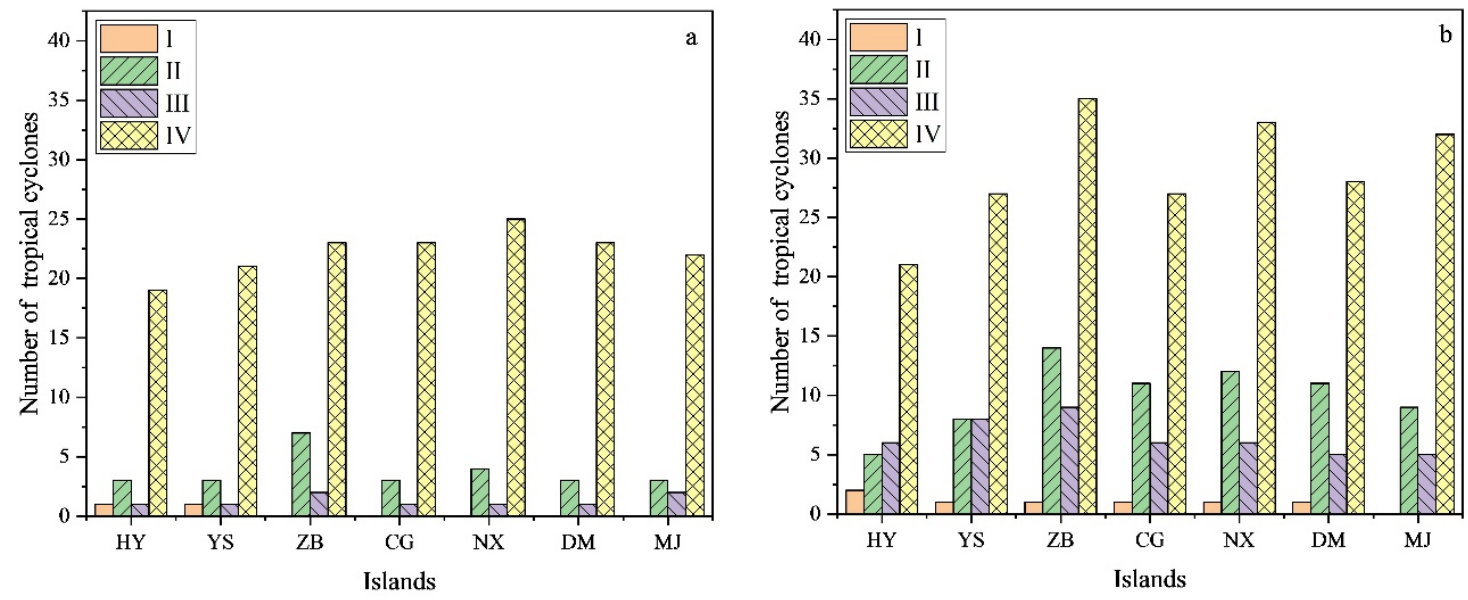

Figure 11. Numbers of TCs in four track patterns. (a) $500 \mathrm{~km}$ radius; (b) $800 \mathrm{~km}$ radius.

Figure 12 shows the contributions of TC precipitation for the four track patterns within the $800 \mathrm{~km}$ radius. Type I occurred once on six of the islands (YS, ZB, NX, CG, HY, and DM) and was absent on MJ island. The average contribution of type I was 26-85.3\%, and the maximum contribution occurred in YS. The average contribution of type II reached 11.5-24\%, and the largest contribution was $88.5 \%$ on YS. For type III, the average contribution was $4.3-29 \%$, and the maximum contribution was $51.2 \%$ on CG. For type IV, the average contribution was $12.8-29.8 \%$, and the highest contribution was $86.8 \%$ in $\mathrm{MJ}$. The islands could be divided into three categories based on the orders of the contribution rates. The first primary order was I (26-85.3\%) > IV (12.8-29.8\%) > III (4.3-29\%) > II (11.5-24\%), represented by HY, ZB, DM. The second order was I > IV > II > III, including YS and NX. The contribution rate for type I was the highest, due to almost all the moisture carried by the TCs falling into the sphere of interest (the circular region within a radius of $800 \mathrm{~km}$ ). The third order was III $>$ IV $>$ II $>$ I, represented by MJ. 

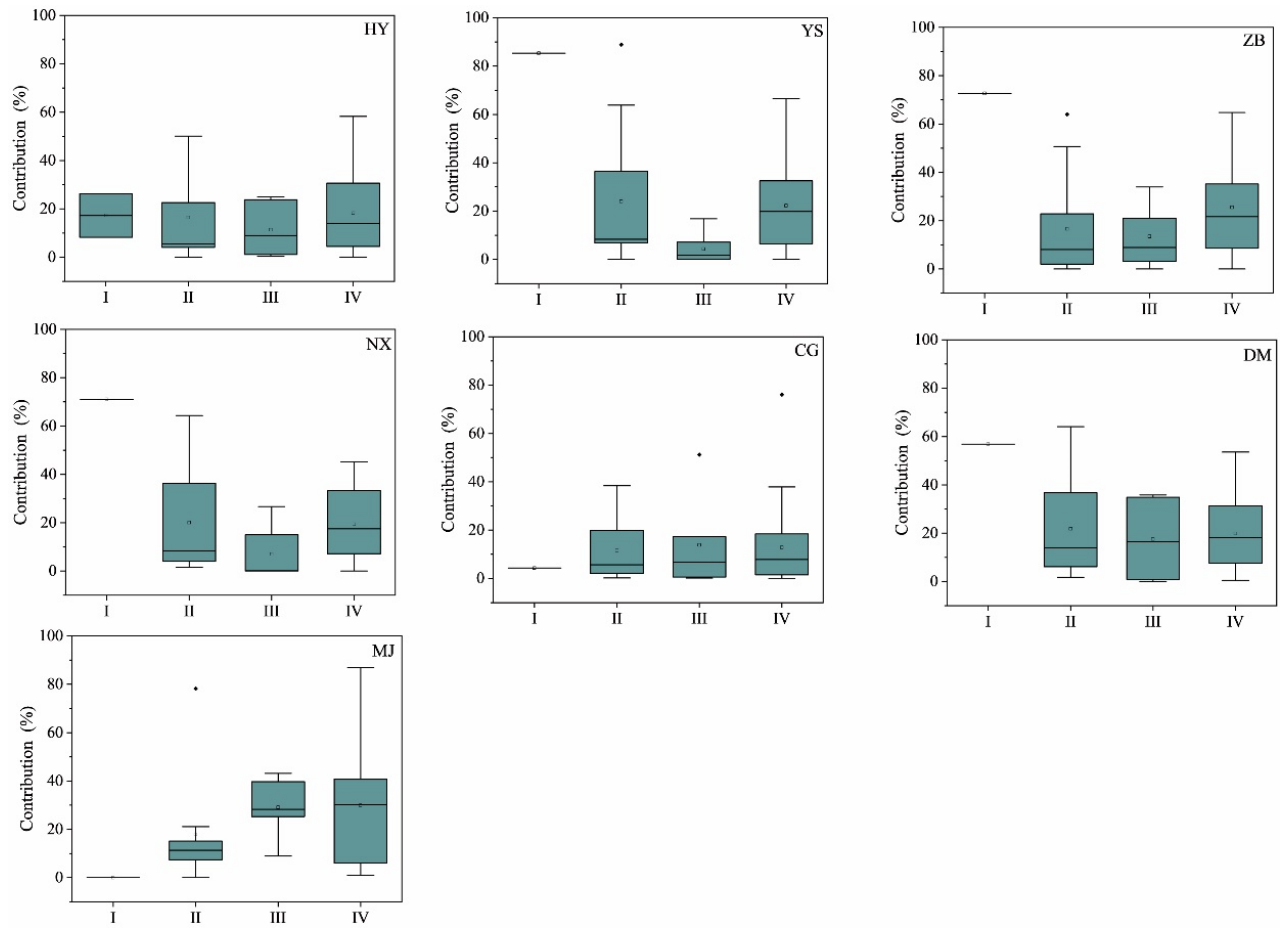

Figure 12. Monthly contribution of TC precipitation for the four track patterns.

\subsection{Impact of ENSO on TC-Derived Precipitation}

After separating tropical cyclone precipitation, the relationship between TC-derived precipitation and ENSO was analyzed. The Pearson correlation coefficients for the ENSO and TC-induced precipitation contribution are shown in Table 2. The coefficients for TC-induced precipitation and ENSO were all negative, but all the islands did not show significant correlation at the 0.01 level with ENSO events for 2001-2018. The contributions of TC-induced precipitation among the seven islands positively correlated with one another at the 0.01 level; in other words, TC-induced precipitation was mainly consistent in the region of the reclaimed islands.

The TC-induced precipitation contributions were obviously more increased in La Niña events than in El Niño events with the alternation of warm and cold SST leading to variations in TCs (Table 3). The peak of SST was the SST at the maximum absolute value of fluctuation. There were six El Niño and eight La Niña events in our study. The largest TC-induced precipitation contributions in El Niño events was in MJ. In the La Niña events, the contributions of TC-induced precipitation were notably higher, and the maximum was $72.3 \%$, in the period of July 2007 to June 2008. In the neutral period, the range of TC-induced precipitation contribution was between La Niña events and El Niño events. The results are similar to those of previous studies in other regions, in that the rainfall was positively correlated with La Niña [40-42]. However, in the seven islands, the TC-induced precipitation contributions exhibited significant spatial variations, as the TC-induced precipitation was asymmetric. The potential physical mechanisms underlying the correlation between TC precipitation and ENSO simply were the reflection in the atmosphere of changes in ocean circulation caused by abnormal sea temperature. Oceanic temperature and ocean current changes will influence the atmosphere and lead to variations of TC precipitation. For example, during the La Niña event, the abnormally cold water is in the central and eastern Pacific Ocean. The southeast trade wind blows the sun-heated seawater to the western Pacific Ocean. The temperature of the sea in the western Pacific Ocean increases, the pressure drops, and humid air accumulates to form the TC precipitation. However, the physical mechanisms between TC precipitation and ENSO were complicated. In a word, ENSO significantly affected the TC-induced precipitation, presenting a challenge for the accuracy of forecasting in the future. 
Table 2. Correlation coefficients for ENSO and TC-induced precipitation.

\begin{tabular}{ccccccccc}
\hline & ENSO & HY & YS & ZB & NX & CG & DM & MJ \\
\hline ENSO & 1 & & & & & & & \\
\hline HY & -0.39 & 1 & & & & & & \\
\hline YS & -0.36 & $0.97^{* *}$ & 1 & & & & & \\
\hline ZB & -0.27 & $0.72^{* *}$ & $0.75^{* *}$ & 1 & & & & \\
\hline NX & -0.16 & $0.82^{* *}$ & $0.83^{* *}$ & $0.88^{* *}$ & 1 & & \\
\hline CG & -0.36 & $0.94^{* *}$ & $0.95^{* *}$ & $0.86^{* *}$ & $0.93^{* *}$ & 1 & & \\
\hline DM & -0.36 & $0.96^{* *}$ & $0.94^{* *}$ & $0.84^{* *}$ & $0.94^{* *}$ & $0.99^{* *}$ & 1 & \\
\hline MJ & -0.27 & $0.71^{* *}$ & $0.67^{* *}$ & $0.92^{* *}$ & $0.85^{* *}$ & $0.79^{* *}$ & $0.81^{* *}$ & 1 \\
\hline & & & & & & &
\end{tabular}

Table 3. ENSO and TC-induced precipitation contribution.

\begin{tabular}{|c|c|c|c|c|c|c|c|c|c|}
\hline \multicolumn{3}{|c|}{ ENSO } & \multicolumn{7}{|c|}{ TC-Induced Precipitation Contribution (\%) } \\
\hline Event & Time length & Peak & $\mathrm{HY}$ & YS & $\mathrm{ZB}$ & NX & CG & $\mathrm{DM}$ & MJ \\
\hline \multirow{6}{*}{ El Niño } & $2002.06-2003.02$ & 1.3 & 0 & 0 & 0 & 0 & 0 & 0 & 0 \\
\hline & 2004.07-2005.02 & 0.7 & 0.9 & 1.4 & 34.7 & 7.8 & 1.5 & 1.2 & 36.1 \\
\hline & 2006.09-2007.01 & 0.9 & 0 & 0.1 & 0.1 & 0 & 0 & 0 & 0 \\
\hline & $2009.07-2010.03$ & 1.6 & 0 & 0 & 0.6 & 0 & 0 & 0 & 0 \\
\hline & 2014.11-2016.05 & 2.6 & 1.4 & 9.1 & 13.6 & 31.1 & 7.9 & 9.0 & 16.8 \\
\hline & 2018.10-2018.12 & 0.9 & 3.1 & 11.0 & 25.9 & 17.3 & 15.9 & 9.5 & 1.2 \\
\hline \multirow{8}{*}{ La Niña } & 2001.01-2001.02 & -0.7 & 0 & 0 & 0 & 0 & 0 & 0 & 0 \\
\hline & 2005.11-2006.03 & -0.8 & 0 & 0 & 0 & 0 & 0 & 0 & 0 \\
\hline & 2007.07-2008.06 & -1.6 & 44.7 & 72.3 & 56.2 & 46.1 & 48.8 & 42.1 & 41.9 \\
\hline & 2008.11-2009.03 & -0.8 & 0.6 & 7.3 & 6.2 & 1.5 & 1.3 & 0.2 & 0.1 \\
\hline & 2010.06-2011.05 & -1.7 & 0 & 0 & 0 & 0 & 0 & 0 & 0 \\
\hline & 2011.07-2012.03 & -1.1 & 3.9 & 2.3 & 43.8 & 31.1 & 20.1 & 19.2 & 47.3 \\
\hline & 2016.08-2016.12 & -0.7 & 0 & 0 & 0 & 0 & 0 & 0 & 0 \\
\hline & 2017.10-2018.03 & -1 & 57.9 & 61.3 & 44.4 & 48.8 & 48.8 & 50.3 & 51.2 \\
\hline \multirow{13}{*}{ Neutral } & 2001.03-2002.05 & 0.4 & 0 & 0 & 28.5 & 3.3 & 0.2 & 1.9 & 0.3 \\
\hline & 2003.03-2004.06 & 0.4 & 0 & 0 & 14.8 & 9.0 & 3.0 & 3.3 & 3.8 \\
\hline & 2005.03-2005.10 & 0.4 & 1.6 & 11.5 & 16.6 & 20.5 & 8.7 & 15.2 & 8.1 \\
\hline & 2006.04-2006.08 & -1.7 & 0 & 0 & 22.3 & 0.0 & 0 & 0 & 0 \\
\hline & 2007.02-2007.06 & -0.4 & 0 & 0 & 0 & 0 & 0 & 0 & 0 \\
\hline & 2008.07-2008.10 & -0.4 & 0 & 0 & 0 & 0 & 0 & 0 & 0 \\
\hline & $2009.04-2009.06$ & 0.4 & 4.1 & 2.0 & 2.1 & 3.4 & 5.6 & 12.5 & 3.7 \\
\hline & $2010.04-2010.05$ & 0.4 & 0 & 0 & 0 & 0 & 0 & 0 & 0 \\
\hline & 2011.06-2011.06 & -0.4 & 0 & 0 & 0 & 0 & 0 & 0 & 0 \\
\hline & 2012.04-2014.10 & \pm 0.4 & 64.7 & 85.1 & 50.2 & 56.2 & 79.9 & 71.8 & 46.9 \\
\hline & 2016.06-2016.07 & -0.3 & 0 & 0 & 0 & 0 & 0 & 0 & 0 \\
\hline & 2017.01-2017.09 & \pm 0.4 & 0 & 0 & 0 & 0 & 0 & 0 & 0 \\
\hline & 2018.04-2018.09 & \pm 0.4 & 0 & 0 & 0 & 0 & 0 & 0 & 0 \\
\hline
\end{tabular}




\subsection{Uncertainty Analysis}

Based on in situ data from two rain stations, we analyzed the differences in precipitation between the in situ and IMERG data (Figure 13). The in situ and IMERG data by month were similar, except for September, October, and June. Overall, the IMERG data for precipitation were overestimates compared to the in situ data, but the increasing and decreasing trends were consistent (Figure 13a). This error was mainly caused by the IMERG measurements [36]. Additionally, the daily precipitation was compared between the in situ and IMERG data, the error in the daily data obviously being more difficult to determine (Figure 13b). However, the error was still acceptable except for a few points. It was perhaps caused by random error and systematic error in the IMERG data. Briefly, although there were some errors in the IMERG data, they could still reflect the precipitation characteristics of the study area, especially in the absence of actual daily precipitation long-term series (Figure 13c).
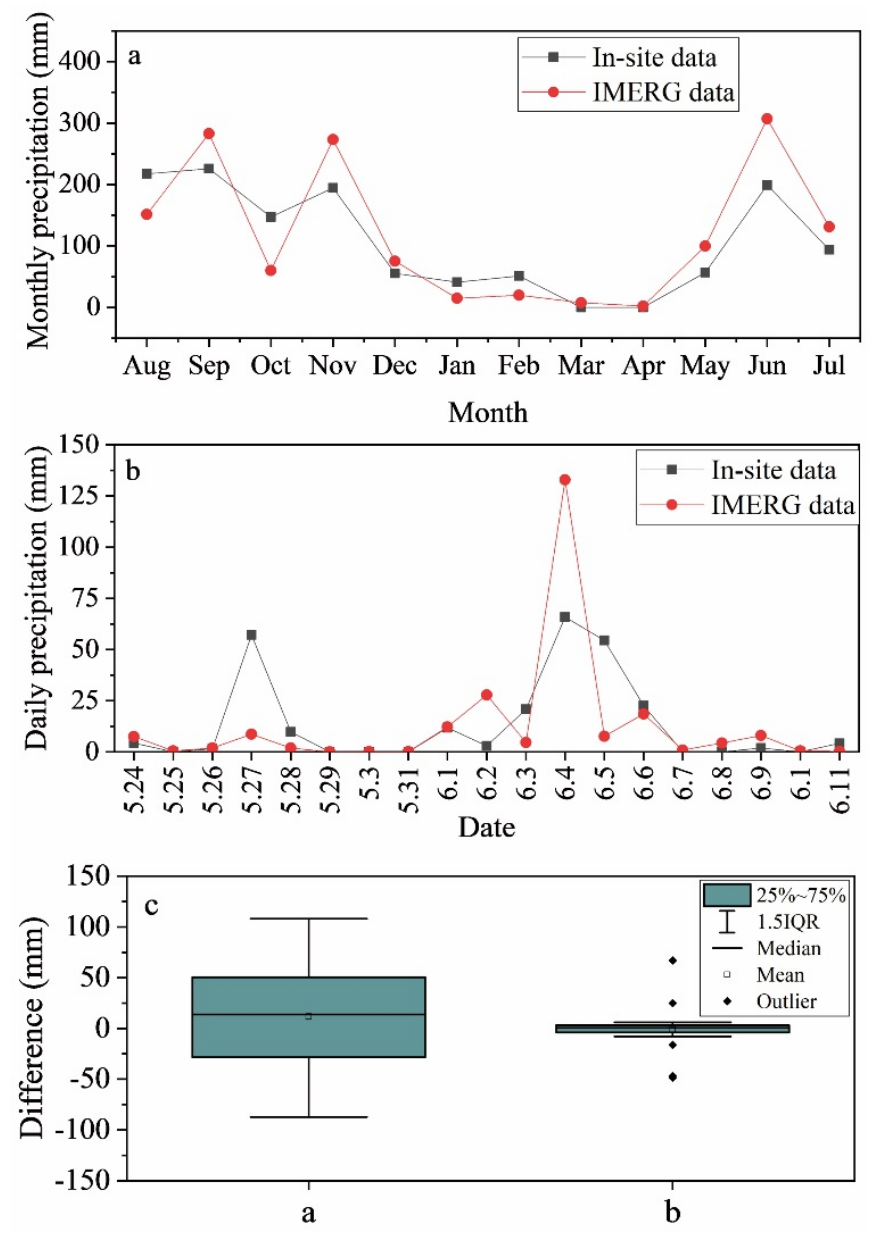

Figure 13. In situ and IMERG data of monthly precipitation in YS (a) and daily precipitation in MJ (b); the box plots indicate the differences between the in situ and IMERG data (c).

\section{Conclusions}

Based on the $6 \mathrm{~h}$ precipitation and the best-track data for each TC collected at $6 \mathrm{~h}$ time intervals from 2001 to 2018, the contribution of TCs to precipitation around the reclaimed islands in the South China Sea was estimated. The ENSO phases were derived from SST anomalies of Niño-3.4. This paper describes the monthly, seasonal, and annual contributions of TCs and the impacts of ENSO, TC track patterns, and the radius of interest on the contributions around the reclaimed islands in the South China Sea. We conclude the following points. 
The contribution of TCs was 5.9 to $10.1 \%$ in the rainy season and 7.9 to $16.8 \%$ in the dry season. This was mainly affected by the influence of the radius on the TC-derived precipitation. The seven islands have the same annual variations in the precipitation contributed by TCs.

An $800 \mathrm{~km}$ radius (the distance between the hourly interpolated tropical cyclone center and island) of interest was better for representing the contribution of TC-induced precipitation than a $500 \mathrm{~km}$ conventional radius around the reclaimed islands in the South China Sea. According to the relationship between the position of the tropical cyclone center and spheres of interest in the motional process of the TCs, four types of track patterns were defined. The order of the primary patterns by contribution was I $(26-85.3 \%)>$ IV $(12.8-29.8 \%)>$ III $(4.3-29 \%)>$ II $(11.5-24 \%)$.

The average distances between the tropical cyclone center and island were 1163 and $712 \mathrm{~km}$ in the rainy and dry seasons, respectively. The relationship between TC-derived precipitation and ENSO indicates that average TCs contribute more during La Niña than El Niño periods around the reclaimed islands in the South China Sea.

The results could be beneficial for managing rainwater resources, especially the TC-induced precipitation in the reclaimed islands, and supplying freshwater to maintain the stability of freshwater lenses in the dry season.

Author Contributions: Conceptualization, D.Y., X.S., and L.Y.; methodology, D.Y.; formal analysis, D.Y., Y.M., and L.Y.; resources, D.Y., X.S., and L.Y.; data curation, D.Y.; writing-original draft preparation, D.Y.; writing-review and editing, D.Y., X.S., L.Y., and Y.M.; visualization, D.Y.; supervision, X.S. and L.Y.; project administration, D.Y., X.S., and L.Y.; funding acquisition, X.S. All authors have read and agreed to the published version of the manuscript.

Funding: This research was funded by Strategic Priority Research Program of the Chinese Academy of Sciences, Grant No. XDA13010303.

Acknowledgments: The authors acknowledge contributions from all members of the project team.

Conflicts of Interest: The authors declare no conflict of interest.

\section{References}

1. Sánchez-Benítez, A.; García-Herrera, R.; Vicente-Serrano, S.M. Revisiting precipitation variability, trends and drivers in the Canary Islands. Int. J. Climatol. 2017, 37, 3565-3576. [CrossRef]

2. Chen, J.M.; Chen, H.S.; Liu, J.S. Coherent interdecadal variability of tropical cyclone rainfall and seasonal rainfall in Taiwan during October. J. Clim. 2013, 26, 308-321. [CrossRef]

3. Wu, Y.; Wu, S.; Zhai, P. The impact of tropical cyclones on Hainan Island's extreme and total precipitation. Int. J. Climatol. 2007, 27, 1059-1064. [CrossRef]

4. Yumul, G.P., Jr.; Servando, N.T.; Suerte, L.O.; Magarzo, M.Y.; Juguan, L.V.V.; Dimalanta, C.B. Tropical cyclone-southwest monsoon interaction and the 2008 floods and landslides in Panay island, central Philippines: Meteorological and geological factors. Nat. Hazards 2012, 62, 827-840. [CrossRef]

5. Rodgers, E.B.; Adler, R.F.; Pierce, H.F. Contribution of tropical cyclones to the north pacific climatological rainfall as observed from satellites. J. Appl. Meteorol. 2000, 39, 1658-1678. [CrossRef]

6. Breña-Naranjo, A.J.; Pedrozo-Acuña, A.; Pozos-Estrada, O.; Jiménez-López, S.A.; López-López, M.R. The contribution of tropical cyclones to rainfall in Mexico. Phys. Chem. Earth Parts A B C 2015, 83-84, 111-122. [CrossRef]

7. Chen, A.; Ho, C.H.; Chen, D.; Azorin-Molina, C. Tropical cyclone rainfall in the Mekong river basin for 1983-2016. Atmos. Res. 2019, 226, 66-75. [CrossRef]

8. Jiang, H.; Zipser, E.J. Contribution of tropical cyclones to the global precipitation from eight seasons of TRMM data: Regional, seasonal, and interannual variations. J. Clim. 2010, 23, 1526-1543. [CrossRef]

9. Khouakhi, A.; Villarini, G.; Vecchi, G.A. Contribution of tropical cyclones to rainfall at the global scale. J. Clim. 2017, 30, 359-372. [CrossRef]

10. Yao, Y.; Andrews, C.; Zheng, Y.; He, X.; Babovic, V.; Zheng, C. Development of fresh groundwater lens in coastal reclaimed islands. J. Hydrol. 2019, 573, 365-375. [CrossRef]

11. Swaffer, B.A.; Habner, N.L.; Holland, K.L.; Crosbie, R.S. Applying satellite-derived evapotranspiration rates to estimate the impact of vegetation on regional groundwater flux. Ecohydrology 2020, 13, e2172. [CrossRef] 
12. Deng, C.; Bailey, R. A modeling approach for assessing groundwater resources of a large coral island under future climate and population conditions: Gan Island, Maldives. Water 2019, 11, 1963. [CrossRef]

13. Bedekar, V.S.; Memari, S.S.; Clement, T.P. Investigation of transient freshwater storage in island aquifers. J. Contam. Hydrol. 2019, 221, 98-107. [CrossRef] [PubMed]

14. Stofberg, S.F.; Essink, G.H.P.O.; Pauw, P.S.; de Louw, P.G.B.; Leijnse, A.; van der Zee, S. Fresh water lens persistence and root zone salinization hazard under temperate climate. Water Resour. Manag. 2017, 31, 689-702. [CrossRef]

15. Zhang, W.; Wu, L.; Zou, X. Changes of tropical cyclone tracks in the western north pacific over 1979-2016. Adv. Clim. Change Res. 2018, 9, 170-176. [CrossRef]

16. Wang, L.; Wang, L. Impact of the East Asian winter monsoon on tropical cyclone genesis frequency over the South China Sea. Int. J. Climatol. 2020, 40, 1328-1334. [CrossRef]

17. Chen, J.; Wu, R.; Wen, Z. Contribution of south China Sea tropical cyclones to an increase in southern China summer rainfall around 1993. Adv. Atmos. Sci. 2012, 29, 585-598. [CrossRef]

18. Feng, X.; Wu, R.; Chen, J.; Wen, Z. Factors for interannual variations of September-October rainfall in Hainan, China. J. Clim. 2013, 26, 8962-8978. [CrossRef]

19. Huang, Q.; Guan, Y. Does the Asian monsoon modulate tropical cyclone activity over the South China Sea? Chin. J. Oceanol. Limnol. 2012, 30, 960-965. [CrossRef]

20. Li, R.; Wang, S.Y.; Gillies, R.R.; Buckley, B.M.; Truong, L.H.; Cho, C. Decadal oscillation of autumn precipitation in Central Vietnam modulated by the East Pacific-North Pacific (EP-NP) teleconnection. Environ. Res. Lett. 2015, 10. [CrossRef]

21. Zhou, C.; He, L.; Yang, Q.; Fang, Z. Three-dimensional numerical simulation of freshwater len in coral islands. J. Hydraul. Eng. 2010, 41, 560-566. (In Chinese)

22. Zhao, J.; Wen, Z.; Shu, L.; Zhen, L.; Zhou, C. Formation of freshwater lens in islands and evolution rules of the upconing. Geotech. Investig. Surv. 2009, 37, 40-44. (In Chinese)

23. Chen, J.; Wang, X.; Zhou, W.; Wang, C.; Xie, Q.; Li, G.; Chen, S. Unusual rainfall in Southern China in decaying August during extreme El Nino 2015/16: Role of the Western Indian Ocean and North Tropical Atlantic SST. J. Clim. 2018, 31, 7019-7034. [CrossRef]

24. Hu, P.; Chen, W.; Chen, S.; Liu, Y.; Huang, R.; Dong, S. Relationship between the South China Sea summer monsoon withdrawal and September-October rainfall over southern China. Clim. Dyn. 2020, 54, 713-726. [CrossRef]

25. Gao, S.; Chen, Z.; Zhang, W. Impacts of tropical North Atlantic SST on Western North Pacific landfalling tropical cyclones. J. Clim. 2018, 31, 853-862. [CrossRef]

26. Lok, C.; Chan, J. Changes of tropical cyclone landfalls in South China throughout the twenty-first century. Clim. Dyn. 2018, 51, 2467-2483. [CrossRef]

27. Huang, W.; Dong, S. Long-term and inter-annual variations of tropical cyclones affecting Taiwan region. Reg. Stud. Mar. Sci. 2019, 30, 2352-4855. [CrossRef]

28. Ankur, K.; Busireddy, N.; Osuri, K.; Niyogi, D. On the relationship between intensity changes and rainfall distribution in tropical cyclones over the North Indian Ocean. Int. J. Climatol. 2020, 40, 2015-2025. [CrossRef]

29. Ayala, J.J.H.; Matyas, C.J. Tropical cyclone rainfall over Puerto Rico and its relations to environmental and storm-specific factors. Int. J. Climatol. 2016, 36, 2223-2237. [CrossRef]

30. Barth, N.A.; Villarini, G.; White, K. Contribution of eastern North Pacific tropical cyclones and their remnants on flooding in the western United States. Int. J. Climatol. 2018, 38, 5441-5446. [CrossRef]

31. Hu, H.; Duan, Y.; Wang, Y.; Zhang, X. Diurnal cycle of rainfall associated with landfalling tropical cyclones in China from rain gauge observations. J. Appl. Meteorol. Climatol. 2017, 56, 2595-2605. [CrossRef]

32. Liu, L.; Xu, J.; Wang, Y.; Duan, Y. Contribution of recycling of surface precipitation to landfalling tropical cyclone rainfall: A modeling study for Typhoon Utor (2013). J. Geophys. Res. Atmos. 2019, 124, 870-885. [CrossRef]

33. Lonfat, M.; Marks, F.D.; Chen, S. Precipitation distribution in tropical cyclones using the Tropical Rainfall Measuring Mission (TRMM) Microwave Imager: A global perspective. Mon. Weather Rev. 2004, 132, 1645-1660.

34. Englehart, P.J.; Douglas, A. The role of eastern North Pacific tropical storms in the rainfall climatology of western Mexico. Int. J. Climatol. 2001, 21, 1357-1370. [CrossRef]

35. Kubota, H.; Wang, B. How much do tropical cyclones affect seasonal and interannual rainfall variability over the Western North Pacific? J. Clim. 2009, 22, 5495-5510. [CrossRef] 
36. Huffman, G.J.; Stocker, E.F.D.T.; Bolvin, E.J.; Nelkin, J.T. GPM IMERG Final Precipitation L3 Half Hourly 0.1 Degree x 0.1 Degree V06; Goddard Earth Sciences Data and Information Services Center (GES DISC): Greenbelt, MD, USA, 2019. [CrossRef]

37. Ying, M.; Zhang, W.; Yu, H. An overview of China Meteorological Administration tropical cyclone database. J. Atmos. Ocean. Technol. 2014, 31, 287-301. [CrossRef]

38. Camargo, S.J.; Sobel, A.H. Western north pacific tropical cyclone intensity and ENSO. J. Clim. 2005, 18, 2996-3006.

39. Zhang, W.J.; Zhang, Y.J.; Zheng, D.; Lyu, W.T. Quantifying the contribution of tropical cyclones to lightning activity over the Northwest Pacific. Atmos. Res. 2020, 239, 104906. [CrossRef]

40. Lee, H.S. General rainfall patterns in Indonesia and the potential impacts of local seas on rainfall intensity. Water 2015, 7, 1751-1768.

41. Wang, C.; Wang, B.; Wu, L. Abrupt breakdown of the predictability of early season typhoon frequency at the beginning of the twenty-first century. Clim. Dyn. 2019, 52, 3809-3822. [CrossRef]

42. Liu, F.; Zhang, H.; Ming, J.; Zheng, J.; Tian, D.; Chen, D. Importance of precipitation on the Upper Ocean salinity response to Typhoon Kalmaegi (2014). Water 2020, 12, 614. [CrossRef]

Publisher's Note: MDPI stays neutral with regard to jurisdictional claims in published maps and institutional affiliations.

(C) 2020 by the authors. Licensee MDPI, Basel, Switzerland. This article is an open access article distributed under the terms and conditions of the Creative Commons Attribution (CC BY) license (http://creativecommons.org/licenses/by/4.0/). 